\title{
ANALISIS PROPOXUR PADA SAMPEL DARAH POSTMORTEM TIKUS GALUR WISTAR
}

\author{
Azmi Wijayati ${ }^{1}$, Ahmad Basori ${ }^{2}$, Mochammad Yuwono ${ }^{3}$ \\ Sekolah Pascasarjana Universitas Airlangga; Kampus B. Jalan Airlangga Nomor 4-6 Surabaya \\ Jurusan S2 Ilmu Forensik \\ e-mail: azmi.wijayati@gmail.com
}

\begin{abstract}
Abstrak
Bunuh diri menggunakan pestisida merupakan masalah utama di sebagian besar negara di dunia. Kasus fatal bunuh diri akibat keracunan pestisida di negara berkembang umumnya berkisar antara 10-20\%. Propoxur (2-isopropoxyphenyl N-methylcarbamat) adalah insektisida dari golongan karbamat yang dikembangkan oleh Bayer AG, Jerman. Pada kasus toksikologi, pemilihan spesimen postmortem yang cocok untuk dilakukan uji sangatlah penting, jika dibandingkan dengan cabang-cabang lain dalam toksikologi forensik toksikologi Darah merupakan spesimen yang dipilih untuk menghitung dan menenetukan kadar obat dan metabolitnya.

Penelitian ini menggunakan hewan coba tikus galur wistar yang diberi perlakuan peroral propoxur dosis letal. Sampel diambil dari darah jantung tikus dengan tiga variasi waktu yang berbeda yaitu 4, 16 dan 32 jam setelah perlakuan peroral Analisis propoxur dalam sampel darah menggunakan metode ekstraksi cair-cair. Ekstrak diinjeksikan pada GCMS. Hasil GC-MS menunjukkan puncak propoxur dengan waktu retensi 4,6 hingga 4,7. Pola kadar propoxur dalam setiap variabel waktu jam ke 4, 16 dan 32 terdapat kecenderungan penurunan kadar.
\end{abstract}

Kata kunci: propoxur, darah, postmortem, gas chromatography-mass spectrometry

\begin{abstract}
Suicide use pesticide was the main problem in most countries in the world. Fatal cases suicide of poisonous pesticides in developing countries generally ranged from 10-20\% used propoxur. Propoxur (2-isopropoxyphenyl N-methylcarbamate) is an insecticide of the carbamic developed by Bayer AG, German. In the case of toxicology, selection specimens postmortem suitable for undergone a is very important, compared to other branches in toxicology forensic toxicology. Blood was specimens selected for calculating and determine drug metabolites.

This research use animal, rats who were given treatment peroral propoxur letal doses. Blood sample taken from the heart rats with three variation different times that is 4, 16 and 32 hours after treatment peroral. Analysis propoxur in blood sample used liquid-liquid extraction. Extract analysed by GC-MS.The results show the peak of propoxur have retention time 4.6 and 4. Pattern of propoxur levels in each variable hours to 4, 16 and 32 there is a trend of decreasing levels.
\end{abstract}

Keywords: propoxur, blood, postmortem, gas chromatography-mass spectrometry 


\section{PENDAHULUAN}

Keracunan insektisida dapat terjadi akibat kontak langsung melalui inhalasi, parental dan etabol atau disengaja seperti bunuh diri melalui minuman dan makanan. Bunuh diri menggunakan pestisida merupakan masalah utama secara klinik di sebagian besar etabo di dunia (Jeyaratnam, 1990) (Eddleston, 2004), dimana menelan korban sampai 300.000 orang setiap tahun (Eddleston \& Phillips, 2004). Kebanyakan kasus kematian yang terjadi adalah di wilayah pedesaan etabo berkembang (Eddleston, 2004), kasus kematian akibat bunuh diri dengan racun merupakan kondisi nyata yang terjadi di etabo maju (Langley \& Sumner, 2002). Kasus fatal bunuh diri akibat keracunan pestisida di etabo berkembang umumnya berkisar antara 10$20 \%$, tetapi untuk pestisida tertentu dapat mencapai 50-70\% (Eddleston, 2004).

Penyebab tingginya kasus kematian akibat keracunan pestisida bersifat multifaktoral seperti racun bersifat toksik, jarak jauh menuju rumah sakit, fasilitas medis yang kurang lengkap, ketersediaan antidots dan pengalaman tenaga medis dalam menangani kasus keracunan akut (Eddleston, Patterns and problem of deliberate self-poisoningin the developing world, 2004) (Buckley, Karalliedde, Dawson, Senanayake, \& Eddleston, 2004). Dalam kasus bunuh diri menggunakan pestisida maupun insektisida dapat ditentukan insektisida jenis apa yang digunakan dengan cara etabol. Autopsi dilakukan tidak hanya untuk mengetahui jenis racun apa yang digunakan, tetapi juga dapat untuk menentukan interval postmortem (Eddleston \& Phillips, 2004).

Keracunan pada manusia di etabo seluruh dunia yang mengakibatkan keracunan akut yang parah disebabkan senyawa antikolinesterase dan paraquat. Di Costa Rica pada tahun 1980-1986, 3330 orang dirawat dikarenakan keracunan pestisida dan 429 diantaranya meninggal. Penghambat kolinesterase (organofosfat dan karbamat) menyebabkan $63 \%$ penderita dirawat dan $36 \%$ meninggal, sedangkan paraquat menyebabkan $24 \%$ dirawat dan $60 \%$ meninggal. Penghambat kolinesterase juga menyebabkan lebih dari $70 \%$ kecelakaan kerja.

World Health Organozation (WHO) mengestimasikan sekitar 3 juta rumah sakit di dunia melaporkan tentang keracunan pestisida setiap tahun, dengan hasil sekitar 220.000 orang meninggal (Colosio, Vellere, \& Moretto, 2010). Sebagian besar terjadi pada etabo berkembang, terutama di kawasan Asia Tenggara, dan presentase terbesar adalah untuk tujuan bunuh diri lewat saluran pencernaan (Gunnell \& Eddleston, 2003). Estimasi baru mengindikasikan ada sekitar 300.000 orang meninggal akibat bunuh diri menggunakan pestisida setiap tahunnya, dihitung dari sepertiga kejadian bunuh diri secara global (Bertolote, Fleischmann, Eddleston, \& al, 2006) (Gunnell, Eddleston, Phillips, \& Konrasden, 2007). Di beberapa etabo di Amerika tengah dan selatan (El Salvador, Peru), atau di Asia ( Korea, Taiwan) bunuh diri menggunakan pestisida terhitung $50 \%$ hingga 90\% (Ajdacic-Gross, Weiss, \& Ring, 2008)

Propoxur sangat mudah terabsorbsi pada usus mencit ataupun tikus (mendekati $100 \%$ ), hamster, dan sapi. Kurang dai $1 \%$ kandungan propoxur ditemukan pada feses hewan-hewan tersebut. Absorpsi melalui usus pada manusia diperiksa secara laboratorium mempunyai hasil yang etabo sama seperti pada hewan-hewan tersebut. Prinsip dari jalur ekskresi pada hewan dan manusia secara laboratorium menggunakan urin, $95 \%$ dosis terabsorpsi dalam waktu 48 jam.

Propoxur tidak terakumulasi pada beberapa jaringan lunak hewan, kecali terdapat pada ginjal selama proses ekskresi. Pada sapi ditemukan kurang dari 0,1\% kandungan propoxur pada susu. Waktu paruh propoxur pada manusia melalui intravena adalah 8 jam. Akumulasi absorpsi pada kulit hewan dalam waktu 24 jam mendekati 16\% (DPR, 1995). Selama dalam rapid phase dengan waktu paruh $0,18-0,26$ jam, eliminasi propoxur dengan prosentasi 80-95\% terjadi dengan cepat (Foss \& Krechniak, 1980). Pada tikus dalam 16 jam, 90\% dari radiolabel telah terekskresi 5\% pada feses, $25 \%$ sebagai senyawa yang mudah menguap dan $60 \%$ pada urine sebagai konjugat. Onset atau waktu paruh efek klinis dari insektisida propoxur 
tergantung pada dosis, jalur paparan, penggunaan alat pengaman, dan usia dari korban (Rosman, Makarovsky, Bentur, Dushinitky, \& Kriyov, 2009).

Analisis cairan biologi dan cairan ekskresi, biasanya urin, dalam bentuk sediaan atau metabolitnya, dapat dibuktikan dengan cara pengukuran kualitatif dan kuantitatif pengukuran dosis. Keuntungannya adalah menemukan dosis pasif yang dievaluasi secara nyata, dibandingkan dengan potensial, etabol dan integrasi etabol dari semua jalur paparan (Storm, K.K.Rozman, \& Dull, 2000).

Pada kasus toksikologi, pemilihan etaboli postmortem yang cocok untuk dilakukan uji sangatlah penting, jika dibandingkan dengan cabang-cabang lain dalam toksikologi etaboli toksikologi (Skopp, 2004). Postmortem adalah meninggal/setelah kematian dan perubahanperubahan yang timbul setelah kematian. Spesimen yang diambil terkadang kurang dari ideal dan mungkin sudah terdegradasi atau kemungkinan tidak mengandung toksikan. Hasil dari prosedur analisis sangat penting karena dapat digunakan untuk infestigasi kasus sejak beberapa kasus diambil untuk kepentingan etaboli dan dapat mempengaruhi tuntutan etab.

Tujuan melakukan analisis toksikologi pada orang yang sudah meninggal dapat terjadi dari beberapa macam kasus dan tergantung pada peraturan perundangan. Pada beberapa konteks kasus kematian dimana tidak ada rekam medis yang detail tentang suatu perlakuan onatobatan dan tidak ada riwayat sakit sebelum orang itu meninggal maka diperlukan pengujian toksikologi yang komprehensif untuk mengetahui penyebab orang itu meninggal karena obat atau racun (Drummer, 2007).

Darah merupakan etaboli yang dipilih untuk menghitung dan menenetukan kadar obat dan metabolitnya. Konsentrasi toksikan pada darah juga sangat memungkinkan dapat dibandingkan dengan data klinis dan farmakokinetik. Perhitungannya biasanya diambil dari etaboli etabolism, contohnya pada vena femoral untuk menghindari perubahan yang signifikan disebabkan redistribusi toksikan. Penentuan konsentrasi obat pada darah sudah mencukupi pada kasus dimana konsentrasi obat pada takaran fatal dan keracunan. Darah merupakan sampel yang cocok digunakan untuk kasus keracunan gas atau senyawa yang mudah menguap (Skopp, 2004).

Kasus-kasus bunuh diri dengan propoxur (baygon) banyak terjadi di Indonesia. Terkadang korban ditemukan sudah meninggal dengan botol insektisida disampingnya. Dalam mengetahui penyebab korban meninggal harus dilakukan etabol. Autopsi dilakukan untuk mengetahui jenis racun apa yang telah digunakan untuk bunuh diri, tetapi juga untuk mengetahui kapan korban melakukan bunuh diri.

Sejauh ini penelitian dan pemecahan kasus keracunan propoxur atau Baygon di Indonesia masih sebatas uji kualitatif. Uji kualitatif hanya menentukan apakah suatu sampel positif mengandung suatu senyawa X. Uji kualitatif tidak memberikan hasil tentang kadar suatu senyawa pada sampel. Ketika suatu kasus keracunan maka butuh data akurat tentang suatu senyawa tersebut, termasuk kadar yang berada pada sampel. Penentuan Limit of detection (LOD) dan limit of quantitacy (LOQ) juga sangat berpengaruh dalam penentuan kadar insektisida propoxur. LOD dan LOQ merupakan jumlah terkecil analit dalam sampel yang dapat dideteksi dan masih memberikan respon signifikan dibandingkan dengan larutan standar. Batas deteksi merupakan uji batas. Batas kuantitasi adalah parameter pada analisis renik dan diartikan sebagai kuantitas terkecil analit dalam sampel yang masih memenuhi etaboli cermat dan seksama (Harmita, 2004).

Pentingnya untuk mengetahui kadar dari suatu zat dalam suatu sampel barang bukti adalah untuk menguatkan bukti penyelidikan. Penelitian ini merujuk pada penentuan kadar propoxur pada hewan coba dengan dosis $2 \mathrm{LD}_{50}$ dan $3 \mathrm{LD}_{50}$ dan dengan variasi waktu pengambilan sampel. Variasi waktu pengambilan sampel adalah waktu paruh dari propoxur dan lima kali waktu paruh dari propoxur, karena ketika pengambilan sampel lima kali waktu paruh dimungkinkan propoxur sudah terekskresi sebanyak 95\%. Profil kandungan propoxur pada sampel post mortem pada penelitian dimungkinkan dapat menjadi acuan dalam 
penentuan kadar pada kasus keracunan propoxur yang berakibat kematian yang dipengaruhi dosis paparan dan waktu pengambilan sampel.

Pengujian sampel menggunakan instrumen GC-MS. GC-MS merupakan metode yang efektif dan efisien dalam analisis kadar insektisida khususnya propoxur. Propoxur mempunyai sifat yang mudah menguap. Teknik analisis yang menjadi pilihan pertama untuk memisahkan senyawa-senyawa yang mudah menguap adalah menggunakan GC.

\section{Tinjauan Pustaka}

Pestisida pertama kali diperkenalkan di Indonesia pada tahun 1970-an bertepatan dengan pelaksanaan program intensifikasi pertanian padi dan tanaman pangan lain yang bertujuan untuk meningkatkan produktifitas. Pestisida sintetik menjadi maslah lingkungan di Indonesia pada tahun 1970-1980, karena saat itu pemakaian pestisida yang berlebihan dengan adanya program pemerintah dalam intensifikasi pertanian yang menyebabkan keracunan akut dan kronis pada hewan dan manusia (Resosudarmo, 2001).

Paparan terhadap pestisida dapat masuk ke dalam tubuh manusia melalui tiga cara yaitu dengan absorpsi melalui kulit atau mata (dermal), melalui mulut (oral) dan melalui pernapasan menuju paru-paru (inhalasi) (Larry, Clyde, \& Vitzhum, 2001). Paparan melalui kulit menghasilkan etabol yang sangat cepat setelah pestisida kontak dengan kulit atau mata.

Paparan melalui kulit kemungkinan akan sangat memberikan efek yang sangat serius. Dari perspektif kuantitatif, paparan melalui mulut berada pada dosis dugaan yang memiliki kurva respon sangat ekstrim. Dosis minum yang tinggi, membuat keracunan yang parah dan kematian, dapat terjadi sebagai akibat dari menelan pestisida untuk tujuan bunuh diri, atau tertelan tanpa sengaja, biasanya disebabkan penyimpanan dalam wadah yang tidak tepat (Costa, 2008). Paparan melalui pernapasan akan menghasilakn efek yang berbahaya pula karena pestisida mempunyai partikel-partikel yang secara cepat dapat terabsorbsi oleh paru-paru menuju etabo aliran darah (Larry, Clyde, \& Vitzhum, 2001).

World Health Organozation (WHO)

telah merekomendasikan klasifikasi dari pestisida berdasarkan tingkat bahayanya, dimana toksisitas akut dengan cara oral maupun paparan melalui kulit telah dilakukan (IPCS, 2005). Analisis dari data tersebut mengindikasikan bahwa insektisida adalah toksik paling akut. Sekitar 74 komposisi aktif termasuk dalam kelas sangat beracun dan komposisi aktif kelas beracun, 48 diantaranya adalah insektisida (IPCS, 2005).

Di dunia penggunaan pestisida di dominasi oleh herbisida disusul oleh insektisida dan fungisida. Sedangkan di Indonesia, insektisida masih menempati urutan teratas (Djojosumanto, 2000).

Insektisida merupakan bahan yang mengandung senyawa kimia beracun yang eta mematikan semua jenis serangga. Kesulitan dalam pengendalian serangga disebabkan sifatnya yang mudah menyesuaikan diri dengan keadaan sekitar. Untuk membunuh serangga, insektisidan masuk dalam tubuh serangga melalui lambung, kontak dan pernafasan (Wudianto, 2005).

Insektisida terdiri dari beberapa golongan yaitu golongan benzoiluera, karbamat, organoklorin, organofosfat dan golongan peritroid. Organofosfat dan karbamat adalah insektisida yang menghambat kinerja enzim asetikolinesterase, ditunjukkan dengan sinapsis saraf dan persimpangan neuroefektor.

Organofosfat dan karbamat dapat mengakumulasi asetilkolinesterase pada sinapsi muskarnik dan nikotin dan pada CNS (Fauci \& Braunwald, 1997). Golongan karbamat adalah salah satu jenis pestisida yang banyak digunakan dalam bidang pertanian, sebagai insektisida, fungisida, herbisida dan nematosida, selain itu juga banyak digunakan dalam bidang kesehatan sebagai pembasmi etabo penyakit. Salah satu golongan karbamat yang paling banyak digunakan dan mudah diperoleh yaitu propoxur (Prasojo, 1993).

Golongan karbamat sangat menghambat enzim ini. Golongan karbamat terabsorbsi dalam paru-paru, kulit, lambung, 
dan sebagian terdistribusi ke jaringan lunak, dan sangat lambat tereliminasi oleh etabolism hati. Waktu paparan hingga waktu mencapai onset toksisitas bervariasi dari menit hingga berjam-jam, biasanya 30 menit hingga 2 jam (Fauci \& Braunwald, 1997).

Toksisitas karbamat pada mamalia cukup tinggi bila dikonsumsi melalui oral karena daya toksiknya lebih tinggi dibandingkan dengan jenis karbofuran lain dan sifatnya sama dengan insektisida organofosfat yaitu menghambat enzim kolinesterase (Winarno, 1997). Beberapa insektisida yang termasuk golongan karbamat adalah adicarb, karbaril, karbofuran, propoxur, dll.

\subsection{Propoxur}

Propoxur [2(1-metiletoksi)fenol etab karbamat] adalah insektisida jenis karbamat yang dikembangkan oleh Bayer AG, Jerman dan telah terdaftar di U.S Environtmental Protection Agency dan etabo bagian California sebagai pemberantas semut, kecoa, jangkerik, ngengat, nyamuk, lebah, kutu. Propoxur tidak digunakan dalam bidang pertanian (Cochran, 1997). Propoxur bukan merupakan pestisida yang dilarang, dan mengandung 148 bahan yang telah teregistrasi di California. Propoxur dapat digunakan sebagai pengemulsi konsentrasi, bubuk pembasah, dan sebagai pembersih debu pada eksterior gedung. Propoxur dapat juga digunakan sebagai zat tunggal atau dicampur dengan insektisida lain (Cochran, 1997).

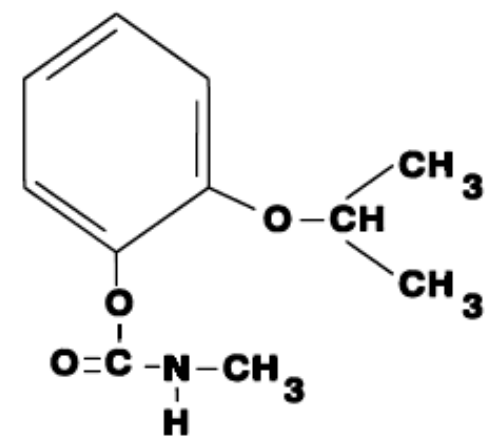

Gambar 1. Struktur Propoxur

Propoxur sangat mudah terabsorbsi pada usus mencit ataupun tikus putih (mendekati 100\%), hamster, dan sapi. Kurang dai $1 \%$ kandungan propoxur ditemukan pada feses hewan-hewan tersebut. Absorpsi melalui usus pada manusia diperiksa secara laboratorium mempunyai hasil yang etabo sama seperti pada hewanhewan tersebut. Prinsip dari jalur ekskresi pada hewan dan manusia secara laboratorium menggunakan urin, 95\% dosis terabsorpsi dalam waktu 48 jam.

Propoxur tidak terakumulasi pada beberapa jaringan lunak hewan, kecali terdapat pada ginjal selama proses ekskresi. Pada sapi ditemukan kurang dari 0,1\% kandungan propoxur pada susu. Waktu paruh propoxur pada manusia melalui intravena adalah 8 jam. Akumulasi absorpsi pada kulit hewan dalam waktu 24 jam mendekati 16\% (DPR, 1995). Onset atau waktu paruh efek klinis dari insektisida propoxur tergantung pada dosis, jalur paparan, penggunaan alat pengaman, dan usia dari korban (Rosman, Makarovsky, Bentur, Dushinitky, \& Kriyov, 2009).

Aktifitas biologi yang utama dari propoxur adalah karbamilasi dari enzim cholinesterase $(\mathrm{ChE})$, mengakibatkaan terjadinya hambatan dari kinerja enzim tersebut. ChE adalah bagian dari enzim yang ditemukan dalam tubuh untuk menghidrolisis kolin ester. Dalam etabo saraf acetylcholinesterase (AchE) terlibat dalam penghentian dorongan di seluruh persimpangan saraf sinapsis termasuk neuromuskuler dengan cepat hidrolisis saraf pemancar, asetilkolin (Bromijon, 1991). Kehadiran inhibitor atau penghambat, asetilkolinesterase menjadi terhambat secara cepat dan tidak lama kemudian menjadi tidak mampu untuk menghidrolisis asetilkolin menjadi kolin dan asam asetat (Jokanovic, 2009).

Penghambatan AchE mengarah pada akumulasi asetilkolin pada celah sinapsis yang mengakibatkan kelebihan stimulasi pada saraf diikuti dengan depresi atau kelumpuhan pada saraf kolinergi sepanjang etabo saraf pusat dan saraf etabolism. AchE sangat selektif, meskipun tidak eksklusif, dengan substrat asetil ester (Bromijon, 1991). Penghambatan enzim dapat terjadi reaktivasi secara spontan, dengan terjadinya pembalikan hambatan dengan waktu paruh paparan satu jam atau kurang (Jokanovic, 2009). Fakta ini kemungkinan dapat digunakan untuk 
mereduksi periode intoksikasi pada kecelakaan dengan paparan propoxur berlebih atau pada kasus bunuh diri. Penghambatan untuk esterase yang lain dimungkinkan dapat terjadi (Thompson, 1999).

Penelitian tentang toksisitas subkronis dan kronis dari insektisida golongan karbamat telah banyak dilakukan, sebagian besar untuk tujuan pendataan dan penemuan utama mereka (penghambatan kinerja kolinesterase, efek pada berat organ dan parameter hematologi) telah dijelaskan (Baron, 1991). Pengembangan tentang ambang toleransi pada propoxur dan karbaril telah diobservasi, dan sudah mencapai pembahasan enzim mikrosomal (Costa, 1981).

Fase toksisitas akut, reseptor muskarinik dan nikotin terstimulasi oleh asetilkolin dengan tanda karakteristik dan tanda mencapai etabolism dan etabo saraf pusat (Murphy, 1986). Stimulasi pada reseptor muskarinik dan nikotin pada etabo saraf pusat dapat menyebabkan sakit kepala, gelisah, insomnia, khawatir, berbicara kacau, gemetar, kehilangan keseimbangan, kehilangan kesadaran, penurunan nafas dan pusat sirkulasi, dan koma (Rosman, Makarovsky, Bentur, Dushinitky, \& Kriyov, 2009).

Kematian dapat terjadi pada keadaan yang sangat buruk, biasanya diawali dengan gagal nafas yang berasal dari efek kombinasi etabolism dan etabo saraf. Pada kasus propoxur, hidrolisis spontan dari kolinesterase karbamat komplek terjadi in vivo, biasanya diawali tanda klinis yang mulai menghilang pada 24 jam (Ellenhorn \& Barceloux, 1988).

Metabolit utama dari propoxur pada manusia, hamster, dan tikus putih adalah 2isopropoksifenol, 2-isopropoksifenil-asam karbamat, 1,2-dihidroksibenzena, 2hidroksifenil metilkarbamat, 2-isopropoksi5-hidroksifenil metilkarbamat, dan 2isopropoksi-4(5)-metoksi-5(4)-hidroksifenil metilkarbamat. Metabolit-metabolit tersebut juga terkonjugasi menjadi bentuk $\mathrm{O}$ glukoronid (Eben, Karl, \& Machemer, Suplementary studies on biotransformation of propoxur in the rat, 1985a).

\subsection{Darah}

Darah dalam sirkulasi mengandung sekitar 4000 sampai 11.000 sel darah putih per mikroliter. Sel darah putih bertanggung jawab terhadap pertahanan tubuh dan diangkut oleh darah ke berbagai jaringan tempat sel-sel tersebut melakukan fungsi fisiologiknya (Sacher, 2004). Dalam keadaan fisiologis, darah selalu berada dalam pembuluh darah, sehingga dapat dijalankan fungsinya sebagai berikut (Handayani \& Hariwibowo, 2008) (1) sebagai alat pengangkut yang meliputi mengangkut oksigen $\left(\mathrm{O}_{2}\right)$ dan karbondioksida $\left(\mathrm{CO}_{2}\right)$; mengangkut sisa-sisa atau ampas dari hasil etabolism jaringan berupa urea, kreatinin dan asam urat; mengangkut sari makanan yang diserap melalui usus untuk disebarkan ke seluruh jaringan tubuh; mengangkut hasil-hasil metabolisme jaringan; (2) mengatur keseimbangan tubuh; (3) mengatur panas tubuh; (4) berperan serta dalam mengatur $\mathrm{pH}$ cairan tubuh; (5) mempertahankan tubuh dari serangan penyakit infeksi, dan (6) mencegah perdarahan.

Sampel darah banyak digunakan untuk studi tentang penentuan (1) uji langsung tentang efek dari senyawa terhadap darah atau sumsum tulang, (2) efek pada organ lain yang diindikasikan kandungannya pada darah, contohnya adalah kebocoran enzim, seperti aspartate aminotransferase, dan (3) kandungan senyawa pada darah atau metabolitnya. Berbagai macam metode dikembangkan dalam pengambilan sampel darah pada tikus putih. Teknik-teknik yang digunakan tergantung pada (1) volume yang dibutuhkan, (2) jika hewan yang digunakan masih bertahan hidup, (3) frekuensi pengambilan sampel, (4) dimungkinkan penggunaan anestesi, (5) seberapa kemungkinn hewan coba bertahan hidup, (6) dampak pada organ yang dihasilkan dari prosedur yang digunakan. 


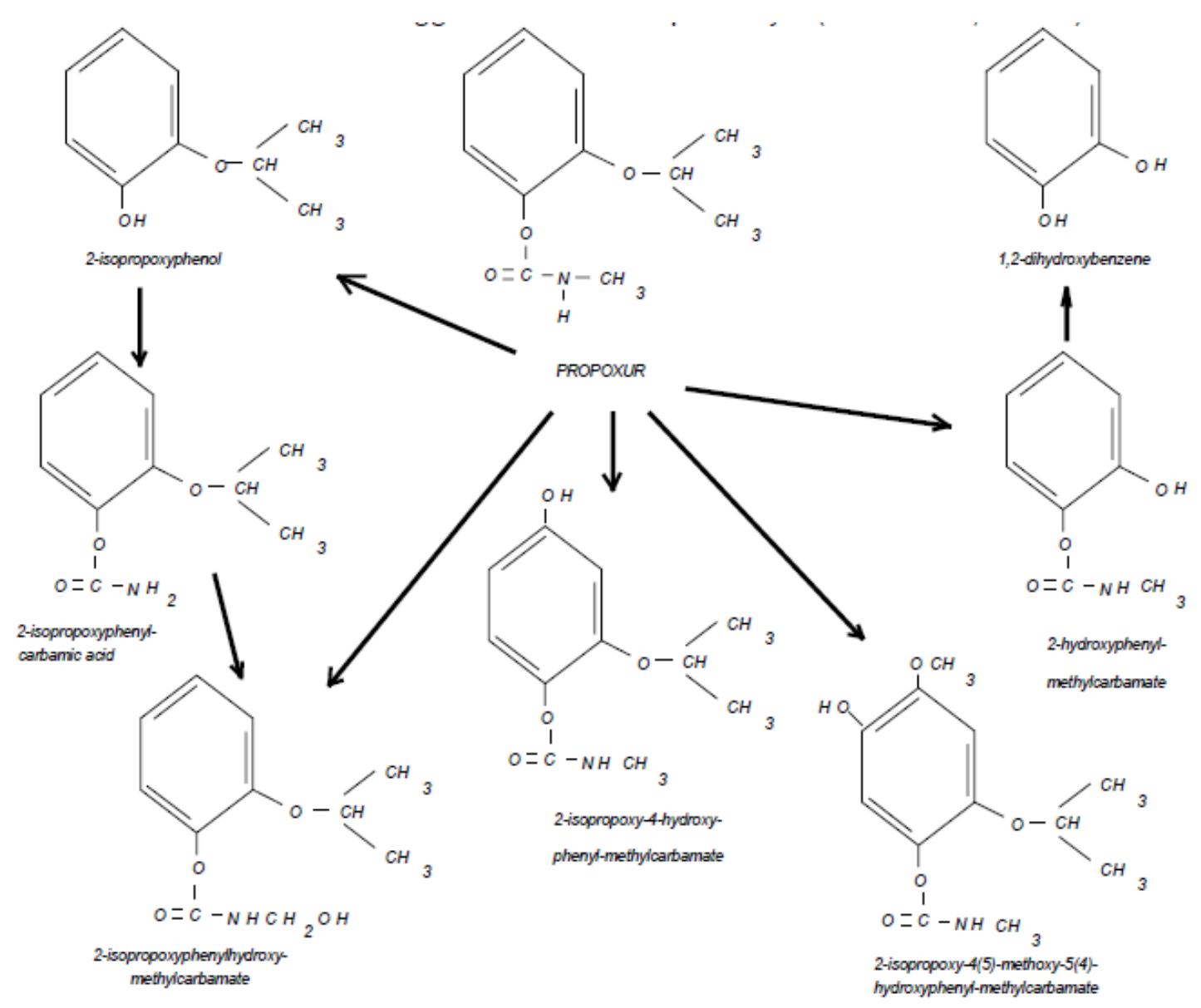

Gambar 2. Metabolit Propoxur 


\subsection{Liquid-liquid Extraction}

Prinsip kerja ekstraksi cair-cair adalah pemisahan senyawa yang mempunyai perbedaan kelarutan pada 2 pelarut yang berbeda. Dalam hal ini ekstraksi cair-cair digunakan untuk memisahan satu atau lebih senyawa menggunakan dua pelarut yang tidak saling bercampur, dimana senyawa akan terdistribusi di antara dua fase sesuai dengan derajat kelarutannya yang kemudian masing-masing jenuh dan terjadi pemisahan

Ekstraksi cair-cair adalah proses pemisahan suatu komponen dari fasa cair lainnya. Operasi ekstraksi-ekstraksi cair-cair terdiri dari beberapa tahap, yaitu (Laddha \& Degaleesan, 1976) :

a. Kontak antara pelarut (solvent) dengan fasa cair yang mengandung komponen yang akan diambil (solute), kemudian solute akan berpindah dari fasa umpan (diluent) ke fasa pelarut (solvent).

b. Pemisahan dua fasa yang tidak saling melarutkan yaitu fasa yang banyak mengandung pelarut disebut fasa ekstrak dan fasa yang banyak mengandung umpan disebut fasa rafinat.

\subsection{GC-MS}

Prinsip kromatografi gas didasarkan atas partisi zat yang hendak dianalisis antara dua fasa yang saling kontak tetapi tidak bercampur. Partisi tercapai melalui adsorpsi atau absorpsi atau keduanya. Sebagai fase gerak digunakan gas pembawa. Bagian pokok dari kromatografi gas adalah injektor, kolom pemisah, dan detektor (Roth \& Blaschke, 1988).

GC-MS mempunyai dua metode analisis yaitu kualitatif dan metode kuantitatif. Waktu retensi tidak dapat mengkonfirmasi identitas peak sehingga dibutuhkan spektrometer massa untuk mengidentifikasi guna analisis kualitatif. Waktu retensi dapat digunakan sebagai identitas suatu sampel apabila variabel kolom tetap konstan, diantaranya panjang kolom, fase diam dan ketebalannya, suhu kolom, dan tekanan (kecepatan alir gas pembawa) (McNair \& Miller, 2009). Analisis kuantitatif membutuhkan pemahaman tentang detektor dan sistem data. Pengambilan sampel, preparasi sampel, validasi metode dan instrumen merupakan bagian penting dalam proses analisis.
Penggunaan spektrometri massa secara luas digunakan di bidang kimia organik sejak tahun 1960. Terdapat dua alasan utama penggunaan MS, yang pertama karena mampu memguapkan hampir semua senyawa organik dan mengionkan uap; kedua, fragmen bermuatan yang dihasilkan dari molkeul ion dapat dihibungkan dengan struktur molekulnya (Sudjadi, 1988).

Prinsip kerja MS adalah analit diuapkan dalam keadaan vakum kemudian dialirkan menuju ruang pengion, analit ditembak dengan arus partikel berenergi tinggi menghasilkan ion dengan kelebihan energi (radikal ion) yang bisa memecah dan tidak bisa memecah. Ion yang bisa memecah disebut ion induk (parent ion), ion induk akan memecah menjadi ion positif, negatif, dan netral. Ion negatif akan tertarik ke anoda untuk dinetralkan dan terhisap oleh pompa vakum bersama-sama dengan fragmen netral, sedangkan partikel bermuatan positif menuju ke tabung analisator dan dibelokkan oleh medan magnet sehingga lintasannya melengkung (Fessenden \& Fessenden, 1989).

Pada MS, hanya ion positif yang terdeteksi dan disajikan sebagai grafik yang memuat puncak $\mathrm{m} / \mathrm{z}$ (massa/muatan) ion-ion yang intensitasnya tergantung pada kelimpahan relatif ion. Puncak tertinggi pada spektrum disebut sebagai puncak dasar (base peak), dinyatakan dengan nilai $100 \%$ dan molekulnya dinyatakan sebagai presentase puncak dasar tersebut. Puncak ion molekul umumnya merupakan puncak-punck dengan bilangan massa tertinggi, kecuali jika terdapat puncak isotop. Puncak-puncak isotop ada karena sejumlah molekul tertentu mengandung isotop lebih berat dari pada isotopnya. Pecahnya suatu ion-ion atau molekul menjadi fragmen-fragmen tergantung pada kerangka karbon dan gugus fungsional yang ada. Oleh karena itu, struktur dan massa fragmen memberikan petunjuk mengenai struktur molekul induknya (Fessenden \& Fessenden, 1989).

\section{METODE PENELITIAN 3.1 Bahan}

Sampel yang digunakan adalah plasma darah tikus galur wistar. Bahan kimia (pro analisis) yang digunakan acetonitril, Nacl, metanol, standar propoxur. 


\subsection{Instrumen Penelitian}

Instrumen yang digunakan pada penelitian ini adalah GC yang digunakan Agilent 6890 GC (Agilent Technologies, Shanghai, China), dilengkapi dengan injektor otomatis Agilent 6890 yang dipasangkan dengan detektor selektif massa Agilent 5975.

\subsection{Ekstraksi Sampel}

Sebanyak $50 \mu 1$ spesimen (darah) dicampur dengan $5 \mathrm{ml}$ asetonitril dan larutan internal standar, dihomogenkan dan disentrifuse pada $3000 \mathrm{rpm}$ selama 5 menit untuk membersihkan larutan. Diperoleh endapan, ekstraksi diulangi 2 kali. Larutan bening asetonitril yang diperoleh kemudian dicampur dengan larutan $\mathrm{NaCl} 2 \%$ sebanyak $40 \mathrm{ml}$ dan $\mathrm{n}$ heksana/etil asetat sebanyak $12,5 \mathrm{ml}$ $(1: 1$, v/v) pada corong pisah $250 \mathrm{ml}$. Corong pisah dikocok selama 10 menit menggunakan mesing pengaduk. Lapisan n-heksana/atil asetat terbentuk. Lapisan tersebut dikeringkan pada suhu kamar. Larutan sisa dilarutkan dengan $200 \mu \mathrm{l}$ metanol. Sampel siap diinjeksikan ke GC-MS sebanyak $1 \mu \mathrm{l}$.

\subsection{Kondisi GC-MS}

GC yang digunakan Agilent 7890A

GC (Agilent Technologies, Shanghai, China), dilengkapi dengan injektor otomatis Agilent 7683 yang dipasangkan dengan detektor selektif massa Agilent 5975. Helium dengan tekanan atas $50 \mathrm{kPa}$ digunakan sebagai gas pembawa. Suhu dari injektor di atur pada $230{ }^{\circ} \mathrm{C}$.

Suhu kolom diatur $60{ }^{\circ} \mathrm{C}$ pada 0 menit $25{ }^{\circ} \mathrm{C} /$ menit hingga $150{ }^{\circ} \mathrm{C}$ ditahan selama 1 menit, kemudian melandai $3{ }^{\circ} \mathrm{C} /$ menit hingga mencapai suhu $240{ }^{\circ} \mathrm{C}$ tahan selama 5 menit; secara bertahap naikkan 10 ${ }^{\circ} \mathrm{C} /$ menit hingga suhu $280{ }^{\circ} \mathrm{C}$ dan tahan selama 10 menit. Gas pembawa yaitu Helium mempunyai kecepatan arus 1,2 $\mathrm{ml} /$ menit, suhu injeksi adalah $230{ }^{\circ} \mathrm{C}$, dengan volume injeksi $1 \mu \mathrm{L}$.

\section{HASIL DAN PEMBAHASAN 4.1 Kadar Sampel}

Berdasarkan hasil pengamatan menggunakan GC-MS, propoxur dapat terditeksi pada tiga variasi waktu pengambilan sampel. Dalam penelitian kali ini setiap variabel penelitian terdapat tiga kali pengulangan dengan total sampel 9 dan 1 untuk kontrol.

Berdasarkan hasil pengujian menggunakan GC-MS diperoleh hasil kadar rata-rata pada jam ke 4 adalah 57,876 ppm, pada jam ke 16 adalah 37,565 ppm, dan pada jam ke 32 adalah 31,427 ppm.

Perolehan kadar ini dengan perhitungan menggunakan kurva linier dengan membandngkan area sampel dengan area internal standar. Pemilihan internal standar dengan syarat masih dalam satu golongan dengan senyawa pada sampel, mempunyai sifat yang hampir sama dan mempunyai waktu retensi yang berbeda.

\subsection{Pengaruh Waktu Pengambilan Sampel dengan Kadar}

Penelitian ini menggunakan satu variabel kadar propoxur yaitu LD50. Konsentrasi suatu senyawa pada fase postmortem dapat dipengaruhi oleh 1) waktu kematian dan posisi kematian; 2) tempat dan waktu pengambilan sampel darah; 3) difusi dari beberapa bagian tubuh; 4) redistribusi; 5) metabolisme; 6) sintesis (Kennedy, 2015). Berdasarkan data yang diperoleh terdapat kecenderungan kadar propoxurnya semakin berkurang semakin lama waktu pengambilan sampel. Pengaruh perbedaan kadar awal pemberian peroral propoxur hanya berpengaruh pada jumlah kadar akhir, tetapi mempunyai pola yang sama. Pola penurunan kadar sangat terlihat dari jam ke 4 hingga jam ke 16, sedangkan pada pengambilan sampel jam ke 32 tidak terlalu terlihat penurunan kadar yang signifikan. Sejauh ini belum ada penelitian acuan tentang kadar propoxur pada sampel post mortem. Beberapa penilitian sebelumnya menggunakan dosis yang bertingkat dari kronis hingga sub-kronis pada tikus hidup. Terdapat kecenderungan pola grafik yang menurun sesuai waktu pengambilan sampel yang lebih lama. Dikarenakan tikus hidup mempunyai sistem absorbsi, distribusi dan metabolisme.

Beberapa literatur ada adalah distribusi morphin pada sampel post mortem darah jantung tikus.

Beberapa penelitian menyebutkan terdapat perbedaan rasio kadar yang dipengaruhi oleh hari setelah waktu 
Jurnal Biosains Pascasarjana Vol. 19 (2017) pp

(C) (2017) Sekolah Pascasarjana Universitas Airlangga, Indonesia

kematian. Kemungkinan perbedaan rasio

kadar tersebut dipengaruhi oleh beberapa

faktor terjadinya pembusukan dari dalam 


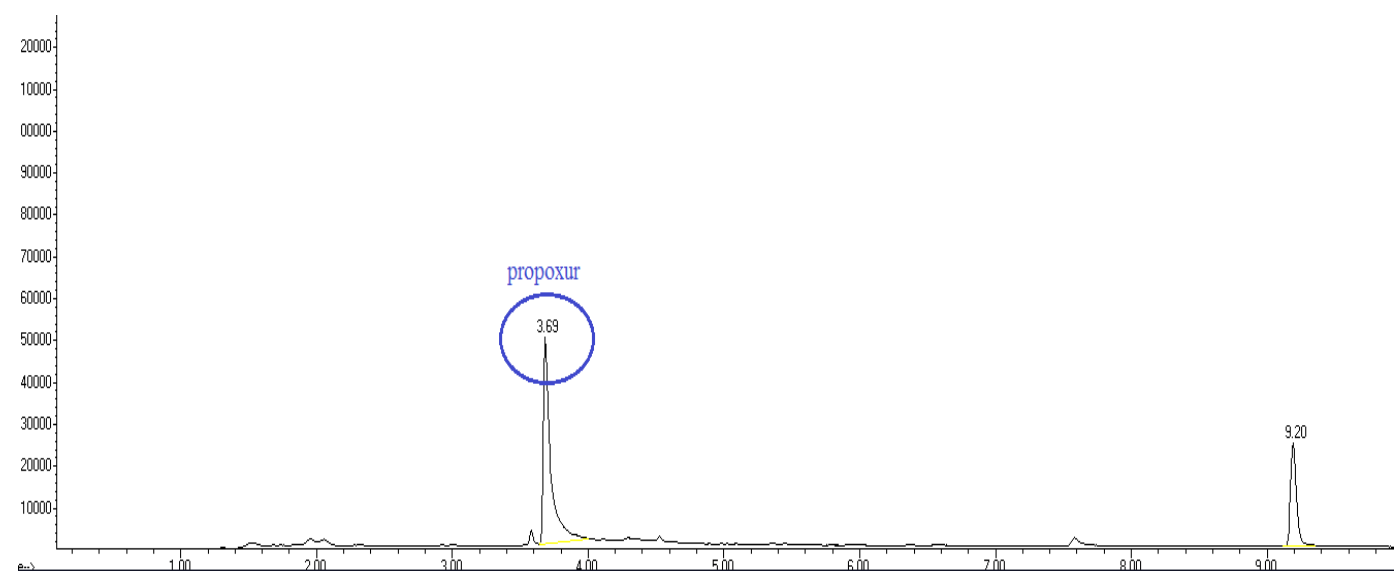

Gambar 3. Pola kromatogram propoxur

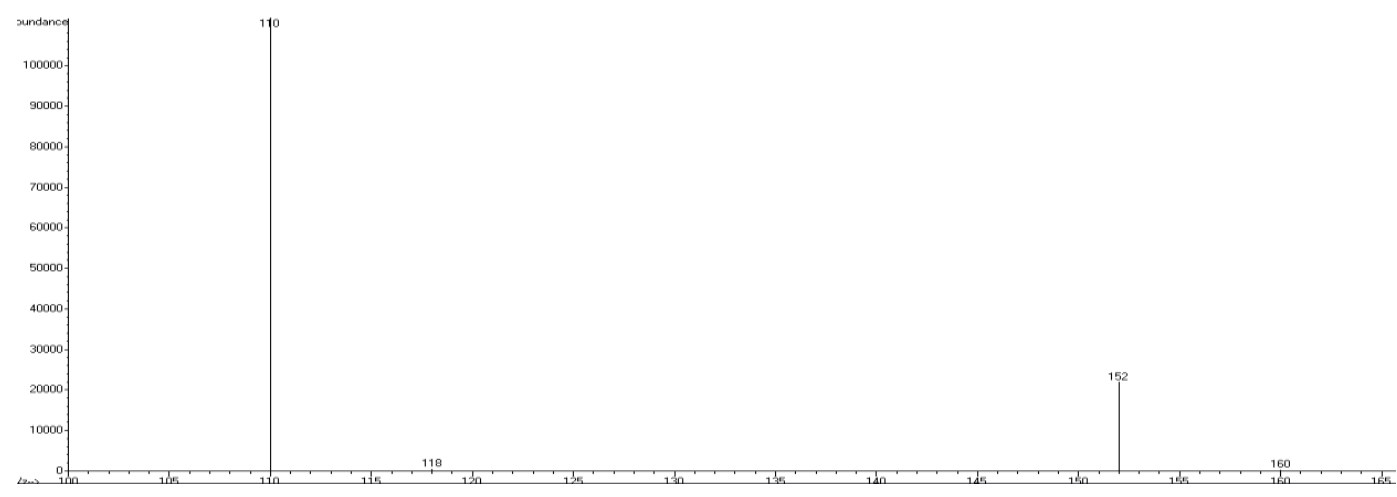

Gambar 4. Spektrum Propoxur

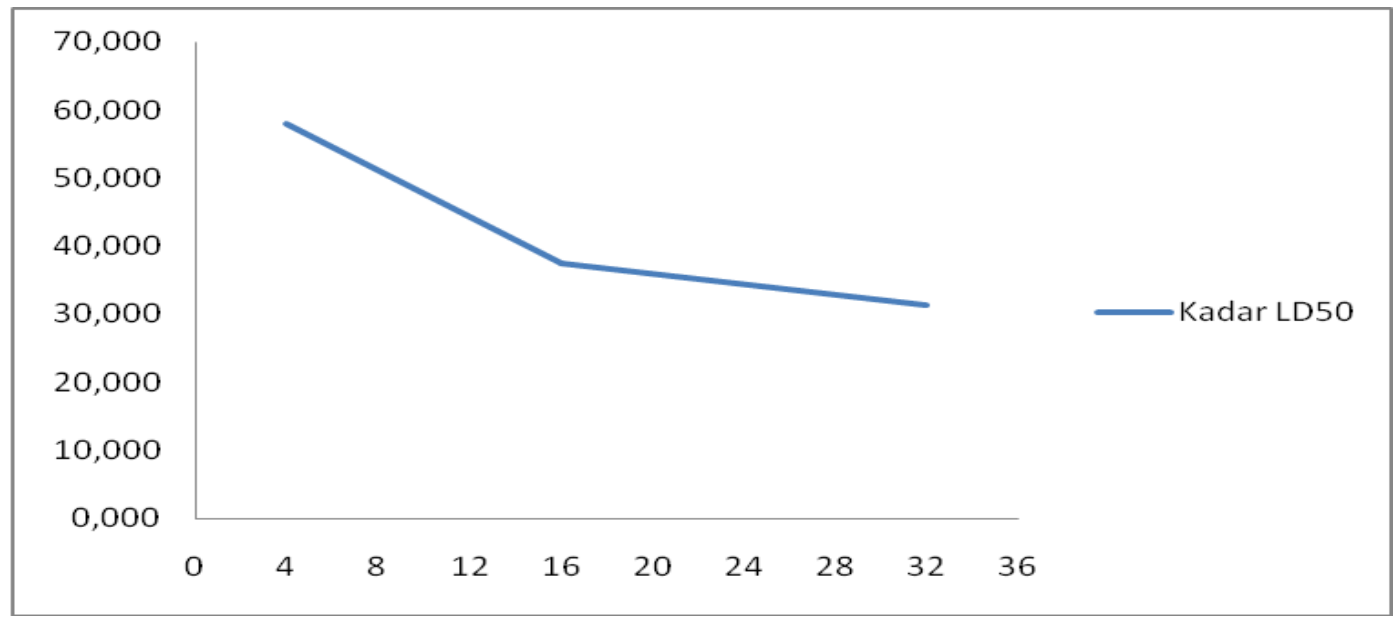

Gambar 4. Profil kadar propoxur dengan waktu pengambilan sampel 

tubuh dan metabolisme bakteri dan ketidakstabilan senyawa kimia (Kennedy, 2015). Contohnya adalah konsentrasi mawar clozapin lebih dari $70 \%$ pada hari ke 4 dan promethazine lebih dari $170 \%$ pada hari ke 3 dan semakin turun konsentrasinya pada hari ke 6 dan ke 5 secara berturut-turut, menunjukkan bahwa masih banyak faktor yang tidak diketahui dan tidak dapat diprediksi mengenai konsentrasi suatu senyawa pada sampel postmortem (Sarr \& Beyer, 2012). Metabolisme suatu senyawa masih dapat terjadi pada post-mortem akibat dari invasi bakteri atau metabolisme tetap terjadi disebabkan oleh aktivitas anzim (Robertson \& Drummer, 1995).

\section{SIMPULAN DAN SARAN}

Pola hubungan antara waktu pengambilan sampel postmortem darah dengan dosis paparan propoxur dalam penelitian ini adalah semakin lama waktu pengambilan sampel, kadar propoxur dalam sampel semakin berkurang.

Perlu penelitian lanjutan dengan sampel postmortem yang berbeda dan waktu pengambilan sampel yang lebih lama.

\section{DAFTAR PUSTAKA}

Ajdacic-Gross, V., Weiss, M., \& Ring, M. (2008). Method of suicide: international suicide patterns derived from the WHO mortality data base. Bull World Health Org , 726-732.

Baron, R. (1991). Carbamate insecticides. In W. Hayes, \& E. Laws, Handbook of pesticide toxicology (pp. 1125 - 1189). San Diego: Academic Press.

Bertolote, J., Fleischmann, A., Eddleston, M., \& al, e. (2006). Deaths from pesticide poisoning: a global response. Br J Psychiatry, 201-203.

Bromijon, S. (1991). Enzymology and biology of cholinesterases. USEPA Workshop on Cholinesterase Methodology (pp. 4-5). U. S.: Environmental Protection Agency.

Buckley, N., Karalliedde, L., Dawson, A., Senanayake, N., \& Eddleston, M. (2004). Where is the evidence for the management of pesticide poisoning is clinical toxicology fiddling while the developing burns? J. Toxicology, 113116.

Cochran, R. (1997). Risk characterization document : Propxur. California: Calivornia Environmental Protection Agency.

Colosio, C., Vellere, F., \& Moretto, A. (2010). Epidemiological studies of anticholinesterase pesticide poisoning : global impact. In T. Satoh, \& R. Gupta, Anticholinesterase Pesticides: Metabolism, Neurotoxicity and Epidemiology (pp. 343-355). New Jersey: Wiley \& Sons.

Costa, L. (1981). Tolerance to the carbamate insecticide propoxur . Toxicology, 267 $-278$.

Djojosumanto, P. (2000). Teknik Aplikasi Pestisida Pertanian. Yogyakarta: Kanisius.

DPR. (1995). Pesticides sold in California by pounds of active ingridients. California: California Protection Agency.

Drummer, O. (2007). Requirements for bioanalytical procedures in postmortem toxicology. Anal Bioanal Chem ; 388 , 1459-1503.

Eben, A., Karl, W., \& Machemer, L. (1985a). Suplementary studies on biotransformation of propoxur in the rat. California: DPR.

Eddleston, M. (2004). Patterns and problem of deliberate self-poisoningin the developing world. J. Med , 42-44.

Eddleston, M., \& Phillips, M. (2004). Self poisodning with pesticides. J. Med , 4244.

Ellenhorn, M., \& Barceloux, D. (1988). Medical Toxicology: Diagnosis and Treatment of Human Poisoning. Elseiver, 1077 - 1080.

Fessenden, R., \& Fessenden, J. (1989). Kimia organik edisi ketiga jilid dua. Jakarta: Erlangga.

Foss, W., \& Krechniak, J. (1980). The fate propoxur in rat. Arch. Toxicol, suppl. 4, 346-349.

Gunnell, D., \& Eddleston, M. (2003). Suicide by intentional ingestion of pesticides: a continuing tragedy in developing countries. Int J Epidemol, 902-909. 
Gunnell, D., Eddleston, M., Phillips, M., \& Konrasden, F. (2007). The global distribution of fatal pesticide selfpoisoning: systematic review. $B M C$ Public Health, 357.

Handayani, W., \& Hariwibowo, A. (2008). Asuhan keperawatan pada klien dengan gangguan sistem hematologi. Jakarta: Salemba Medika.

Harmita. (2004). Petunjuk Pelaksanaan Validasi Metoda dan Cara Perhitungannya. Majalah Kefarmasian Vol 1, pp. 117-135.

Jeyaratnam, J. (1990). Acute pesticide poisoning. World Health Statistic , 139144.

Jokanovic, M. (2009). Medical treatment of acute poisoning with organophosphorus and carbamate pesticides. Toxicol Lett , $107-115$.

Kennedy, M. (2015). Interpreting postmortem drug analysis and redistribution in determining cause of death: a review. Pathology and laboratory medicine international, 5562.

Laddha, G., \& Degaleesan, T. (1976). Transport Phenomena in Liquid-Liquid Extraction. New Delhi: Tata McGrawHill Publishing Co. Ltd.

Langley, R., \& Sumner, D. (2002). Pesticide mortality in the United States 19791998. Vet. Hum. Toxicology, 101-105.

McNair, H. M., \& Miller, J. (2009). Basic Gas Chromatography. 2nd Ed A Wiley interscience, 421-435.

Murphy, S. (1986). Toxic effects of pesticides. In C. Klaassen, The Basic Science of Poisons (pp. 519-581). New York: Macmillan Publishing Co.

Robertson, M., \& Drummer, O. (1995). Postmortem drug metabolism by bacteria. J. Forensic Sci , 382-386.

Rosman, Y., Makarovsky, I., Bentur, Y., Dushinitky, T., \& Kriyov, A. (2009). Carbamate poisoning: treatment recommendations in the setting of a mass casualties event. Am J Emerg Med , 1117-1124.
Roth, H., \& Blaschke, G. (1988). Analisis Farmasi (terjemahan). Yogyakarta: UGM Press.

Sacher, R. (2004). Tinjauan Klinis Hasil Pemeriksaan Labiratorium. Jakarta: ECG.

Sarr, E., \& Beyer, J. (2012). The Timedependant post-mortem redistribution of antipsychotic drugs. Forensic Sci Int , 223-227.

Skopp, G. (2004). Preanalytic aspects in postmortem toxicology. Forensic Science International , 75-100.

Storm, E., K.K.Rozman, \& Dull, J. (2000). Occupational exposure limits for organophosphate pesticides based on inhibition of red blood cell acetylcholinesterase. Toxicology , 1-29.

Sudjadi. (1988). Metode pemisahan, Edisi pertama. Yogyakarta: Kanisius.

Thompson, H. (1999). Esterases as Markers of Exposure to Organophosphates and Carbamates. Ecotoxicology, 369-384.

Wudianto, R. (2005). Petunjuk Penggunaan Pestisida. Jakarta: Penebar Swadaya. 